Historic, archived document

Do not assume content reflects current scientific knowledge, policies, or practices. 



\section{RETURN TO POMOLOGY}

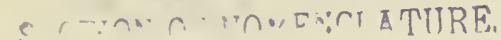

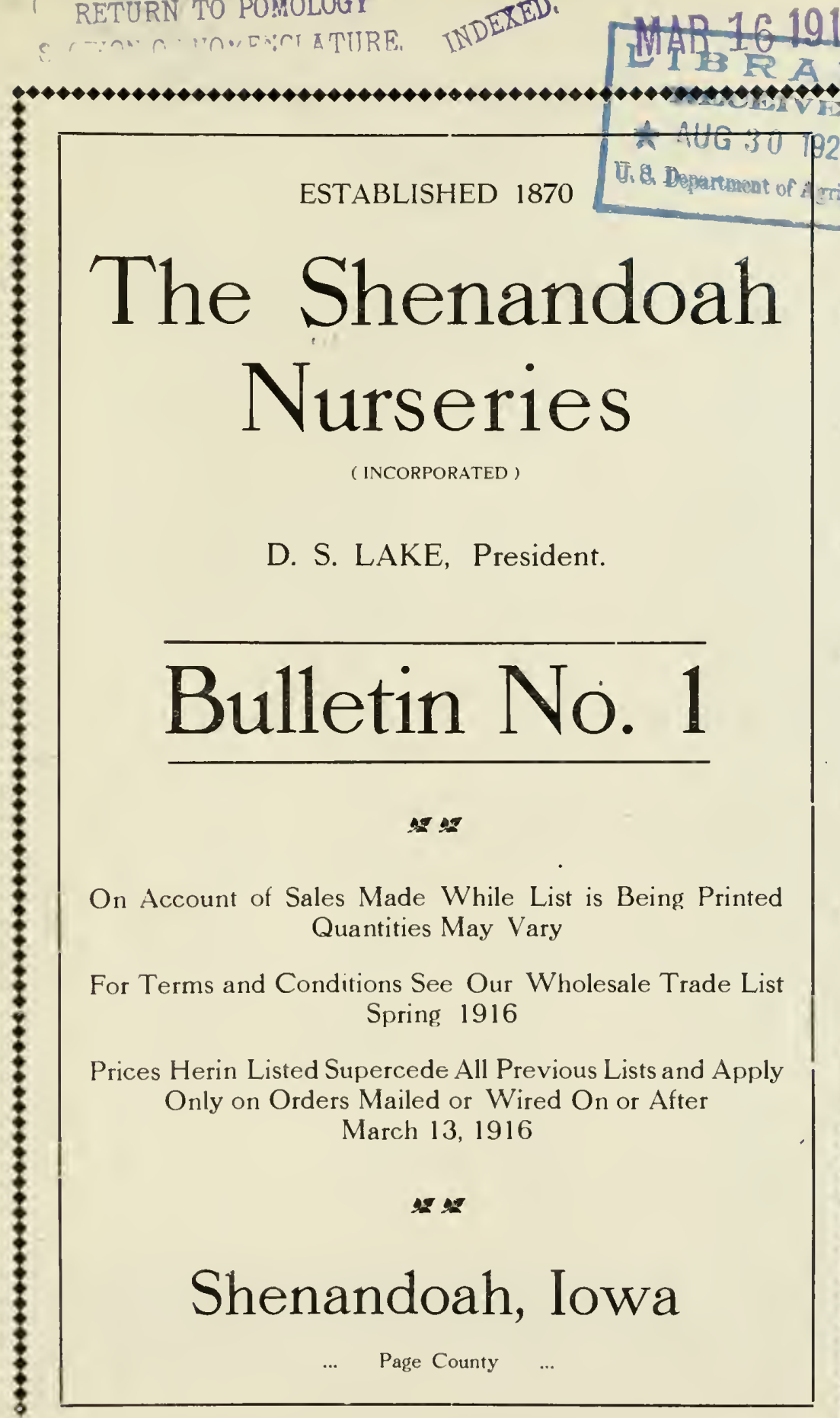




\section{Fruit Department}

\section{Apple}

(Prices as follows unless otherwise noted)

Standard First Class, 5 feet and up, 11-16 in and up

Per 100

$\$ 7 \mathrm{~m}$ !

600

" " " 4 to $5 \mathrm{ft}, 5-8$ to $11-16$ in

" $31-2$ to $+1-2 \mathrm{ft}$., $1-2$ to $5-8 \mathrm{in}$.

$+00$

300
" " " 3 to $+\mathrm{ft}$, slightly branched.

$5-8$ to $11-16$ in $1-2$ to $5-5$ in

200
60 at $51-2 \mathrm{c}$
1020
200
300
40

Benoni

Black Ben Davis

Cooper's Early White

Day

Duchess of Oldenburg.

Early Harvest

Estalline

Famuese.

Gano

Gideon

Golden Russet

Gravenstein

Grimes Golden

Haas

Hibernal

Ingram.

Iowa Beauty.

lowa Blush

Isham Sweet

Janet.

Jonathan

Kaump .

King

King David

Lansingbrug

Lawverb.

Livland Raspberry

Longfied.

Magnet.

Mann

Maiden Blush

M. B. Twig.

McInntosh Red.

Minkler.

Missouri Pippin

Northern Spy

N. W. Greening

Okabena

Opalescent

Peerless

Pewaukee.

Plum Cider

Price Sweet

Rambo

Page 2
50
2800

1650

800

4500

75

430

5000 at $10 \mathrm{c}$

700 at $7 \mathrm{c}$

800 at ic

300

360 at $7 \mathrm{c}$

4100

600

310

5200

650

100

1850

450

800

300

170

1000

50

3800

200

870

390

1300 at $7 \mathrm{c}$

600

175 at $7 \mathrm{c}$

480

700 at $7 \mathrm{c}$

4200

1500

2600

100

1100

7300

40

40

3000

3200

10

400

350
1500 at $51-2 \mathrm{c}$ 1500 at $51-2$

40

250 at $5 \quad 1-2$

290

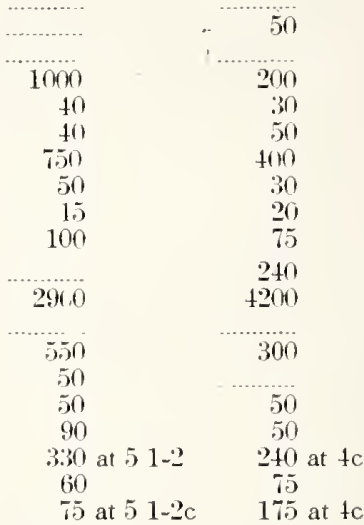

75

400

125

100

275

580

190

500

35

30
100

65 at $4 \mathrm{c}$

25 ()

80

Per 1000

860 (i)

5000

沙 00

$25($ in)

3 to $+\mathrm{ft}$

40

4i)

1000 at $4 \mathrm{c}$

$1+10$ at $4 \mathrm{c}$

50

75 at $4 c$

250 at ic

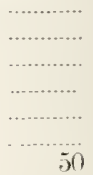

41)

15

150

300

20

to

20

110

300

140

150

100 


\section{Apple-Continued}

11-16in and up $5-8$ to $11-16$ in $1-2$ to $5-8$ in $\quad 3$ to $4 \mathrm{ft}$

Ramsdell Sweet

Red Astrachan

Red Beitigheimer

Red June

Roman Stem...

Rome Beauty

Salome

Shockley

Smith Cider

Spitzenburg

Stark

Stayman Winesap

Summer Queen

Sweel June

Tetofsky

Tolman Sweet

University.

Utter Red

Wagener.

Walbridge.

Wealthy

IV. Astrachan

IV. II: Pearmain

Winesap

Winter Banana

$\mathrm{IV}$ isconsin Russet

W'olf River

Y. N. Pippin

Yellow Transparent

York Inperial

Ile can supply one inch and up

700
900 at ic
350
1100 at ic
50
$(3450$
100
20
20
1000
950
7000
250
2001

son

in)

ili

$25(x)$

250

$1.5(1)$

$350)$

7110

itou

3.50

i.)

(9.)

(j)

3()$)$ at ic

$37(x)$

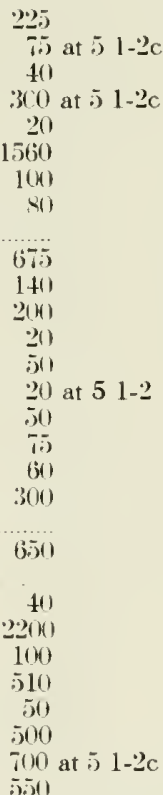

125

two cents per tree

\section{Apple-Crab}

(Prices as follows, unless otherwise noted)

Standard First Class, 5 feet and up, 11-16 inch and up

Per $10 x$

$\$ 700$

(3) 00

400

300

Per 1000 $\$ 60 \mathrm{no}$

$50(\mathrm{No})$

350

25) 010

$31-2$ to $+1-2$ feet, $1-2$ to $\overline{5}-8$ inch

i) to 4 feet, slightly branched

3 to $4 \mathrm{ft}$

Alaska

Darte.

Florence

Hysop

General Grant

Martha

Milton

Queen's C. Cluster

Red Siberian

Shields

Sylvan Sweet

Transcendent

White Arctic

II hitney
$11-16$ inch and up $5-8$ to $11-16$ in

$$
2(k)
$$

60

$3(3)$

40

$2(10$

1(ii)

4.i)

(i)

140

5)

$+40$

1511
20

11)

25)

\section{0}

75

(1)

31)

17i)

10(1)

600

$1-2$ to $5-8$ in

10

$y()$

30

25

35

30

$\underline{2}(1)$

40) at $4 \mathrm{c}$

10()

(i)
70 at $3 \mathrm{c}$

200

135

25

20
40

$\bar{x}$

500

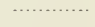




\section{Cherry on Mahaleb}

(Prices as follows, unless otherwise noted)

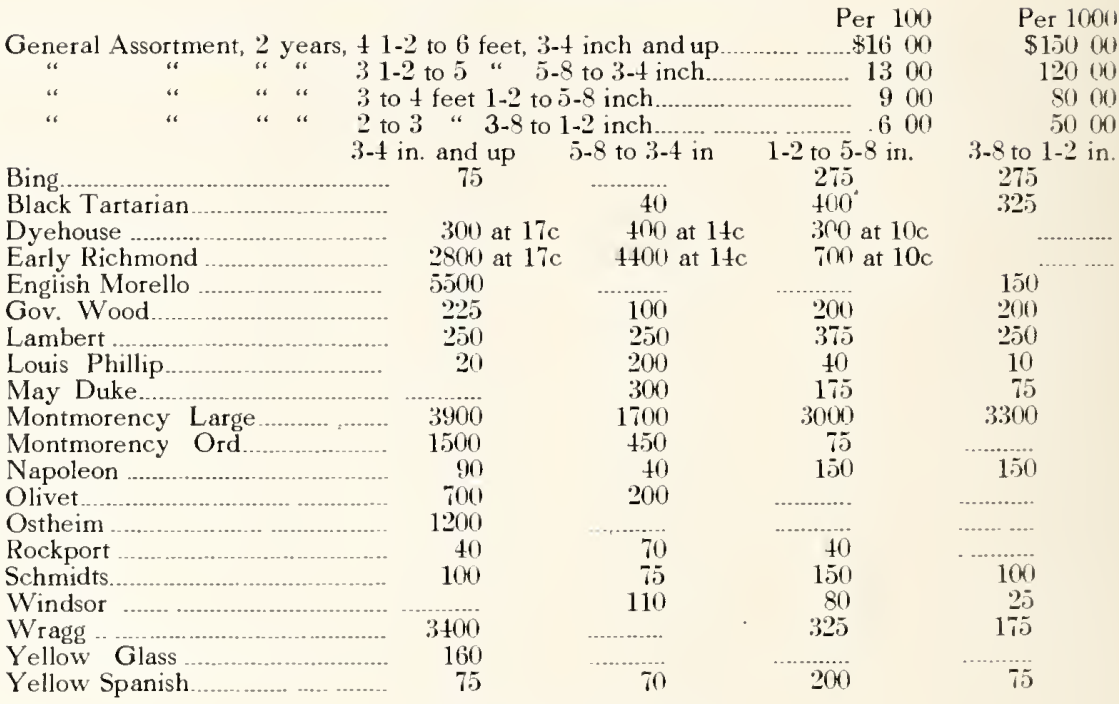

\section{Compass Cherry--Plum}

17002 year, 4 to 6 feet, $9-16$ to $11-16$ inch

Per 100

Per 1000

$\$ 1600$

$\$ 15000$

12000

800 ()

2700 " 3 to 4 feet, $5-16$ to $7-16$ inch

1300

900

1200 " 2 to 3 feet, under 5-16 inch.

600

$50(0)$

\section{Peach}

One year, 5 to 6 feet, $11-16$ inch and up

Per 100 Per 1000

" " 4 to 6 " $9-16$ to $11-16$ inch

Admiral Dewey

$11-16$ in. and $u$

Alexander

Belle of Georgia.......................... 1200

Bokará No. 3.................................. 600

Carman .................................... 1200

Champion............................... 1700

Crawford's Early _................. 2000

Crawford's Late ................................... 1600

Crosby ….................................... 400

Elberta ......................................... 4600

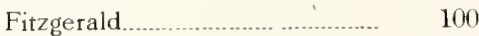

Greensboro …................................ 250

Harrison's Cling .......................... 75

Heath Cling

Lemon's Cling

Mountain Rose
$11-16$ in

100

175

250

450

600

2000

1900

1800

$7-16$ to $9-16$ in $3-9$ to $7-16$ in.
30

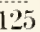

300

500

3100

150

450
.........

30

1200

300

100 


\section{Peach-Continued}

$11-16$ in and up $9-16$ to $11-16$ in $7-16$ to $9-16$ in. $3-9$ to $7-16$ in

Old Mixon Cling

Old Mixon Free

Rav.

Red Bird C'ling

Rusiell

Saluay

Trimiph

Wonderlul

Yellow Saint John

\begin{tabular}{|c|c|c|}
\hline 1.511 & $30(1)$ & \\
\hline 15il & $\because 40$ & 50 \\
\hline 2100 & 30110 & \\
\hline $\bar{B}(1)$ & 70 & 50 \\
\hline $1(11)$ & & \\
\hline (4), & 4110 & () \\
\hline 1(111) & 10110 & \\
\hline (3)11 & 125 & \\
\hline$f, j)$ & 1.50 & \\
\hline
\end{tabular}

\section{Apricot--Buds}

Prices as follows unless otherwise noted)

Per 100

One year. is to (f feet, $11-16$ inch and up

$\$ 1500$

1200

1000

4 to 6 . $9-16$ to $11-16$ inch

i- 16 to $9-16$

$7-16$ to $9-16$ in.

Hexis

Ey: Golden

$11-16$ in. and up $9-16$ to $11-16$ in

6()

Ev. Nay

Vloorpark

Roval

Russian Seedlings

Superb

II ilson

\begin{tabular}{|c|c|c|}
\hline \multirow[b]{2}{*}{30} & & 60 \\
\hline & $7 \overline{10}$ & 50 \\
\hline & & 1,50 \\
\hline in & & 200 \\
\hline $1: 5$ & in & \\
\hline$\because 20$ at $10 \mathrm{c}$ & & 100 at $6 \mathrm{c}$ \\
\hline 64 & 18 & $2.51)$ \\
\hline & $\lambda(3)$ & 1011 \\
\hline
\end{tabular}

\section{Nectarines}

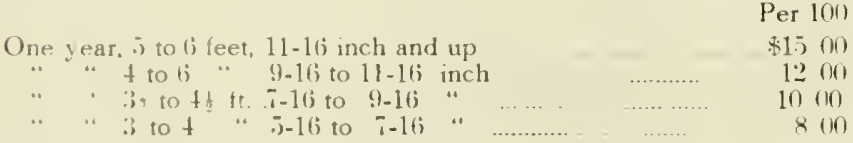

Red Roman

White Roman
$11-16 \mathrm{in}$ and up $9-16$ to $11-16$ in $7-16$ to $9-16$ in. $5-16$ to $7-16$ in $10 \quad 20$

40

\section{Pear--Standard}

Prices as follows unless otherwise noted. Budded on French Branched Seedlings)

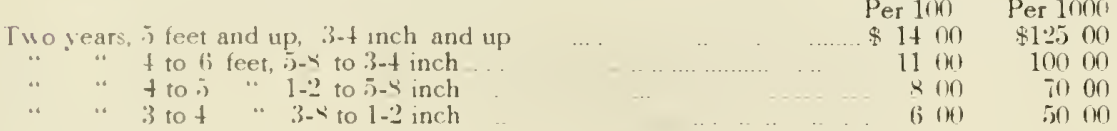

Bartlett

B. D. Anjou

Clapp's Favorite

Duchess d'Angouleme

Flemish Beauty

Garber

Keffer

Seckel

Sheldon

Vermont Beauty

Vilder
$3-4$ inch and up $160(x)$

$.5)(1$

1700

$\because 7$

(Ix)

$2 \times(x)$

J.j) at (ic

2 (n)

i.)

10)

$1+11$ i)- 2 to $3-\frac{t}{\text { in }}$.

1900

275

i(li)

il

3.50

(j) at at

240

3.)

$\times 0$

50

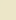




\section{Pear Dwarf}

\begin{tabular}{|c|c|}
\hline & Per 100 \\
\hline Two years, 11-16 inch and up & $\begin{array}{r}\$ 1000 \\
800\end{array}$ \\
\hline " " $1-2$ to $5-8$ inch & 600 \\
\hline " $3-8$ to $1-2$ " & +00 \\
\hline
\end{tabular}

11-16 in. and up 5-8 to $11-16$ in, $1-2$ to $5-9$ in

\begin{tabular}{|c|c|c|c|}
\hline \multirow{2}{*}{\multicolumn{4}{|c|}{$\begin{array}{l}\text { Bartlett .............. } \\
\text { B. D. Anjou }\end{array}$}} \\
\hline & & & \\
\hline Clapps Favorite & 190 & 70 & 20 \\
\hline Duchess 'd Angouleme... & 300 & 60 & \\
\hline Garber & 600 & 75 & 10 \\
\hline Kieffer. & 950 & 100 & \\
\hline Seckel .................... & $\ldots \ldots$ & 45 & 15 \\
\hline Flemish Beauty ........... & 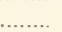 & 100 & \\
\hline
\end{tabular}

\section{Quince}

Two years, 5 feet and up, 11-16 inch and up. ............... 1500

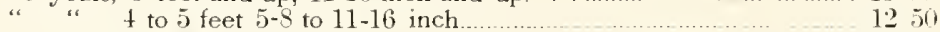

" " "3 to $t$ " $1-2$ to $5-8$ "

" " 2 to 3 " under 1 "2 "

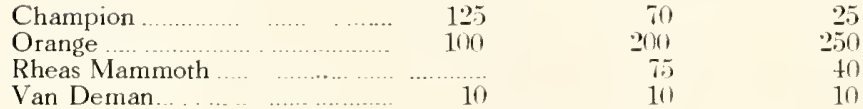

11-16 in. and up 5-9 to $11-16$ in. $1-2$ to $5-8$ in. Under $1-2$ in

\section{Mulberry}

Downing, Whips

New Anerican.

Russian

\begin{tabular}{|c|c|c|c|}
\hline \multicolumn{4}{|c|}{ Mulberry } \\
\hline 6 to 8 feet, & $\begin{array}{l}5 \text { to } 6 \text { feet. } \\
100 \text { at } 20 \mathrm{c}\end{array}$ & $\begin{array}{l}+ \text { to } 5 \text { feet } \\
175 \text { at } 15 \mathrm{c}\end{array}$ & 3 to + feet \\
\hline 150 at $10 \mathrm{c}$ & 17 at ic & 725 at $5 \mathrm{c}$ & 900 at $3 \mathrm{c}$ \\
\hline
\end{tabular}

Plum-0n Native Roots

Americana and Chicasaw Varieties at following prices unless otherwise noted.

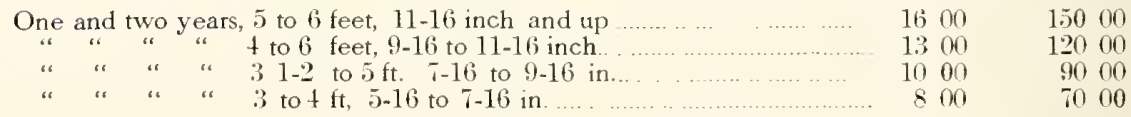

11-16 in and up, $9-16$ to $11-16$ in, $7-16$ to $9-16$ in, $5-16$ to $7-16$ in

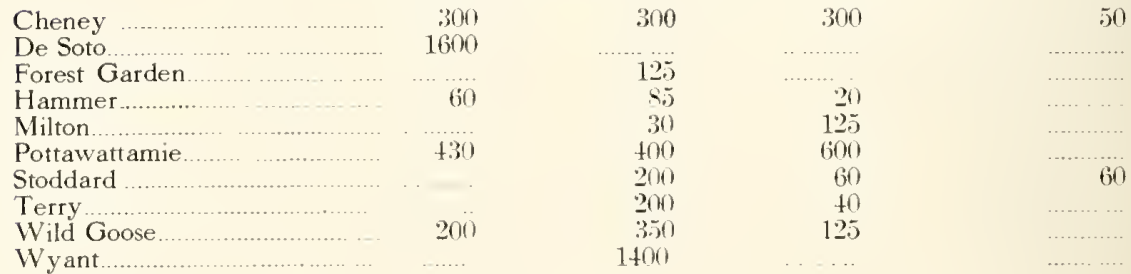

Page 6 


\section{Plum-0n Native Roots}

Hansen Hybrids

One and two years, is to 6 feet, $11-16$ inch and up

Per 100
51800
1500
1200
1000

Per 10110

" " " " t

" " " " "3 $1-2$ to $5 \mathrm{ft}, 7-16$ to $9-16$ in

$10(10)$

11-16 in and up, 9-16 to $11-16$ in, $7-16$ to $9-16$ in

Hanska
Huya
Kaga
Opata
Sapa
Wastesa
Yuteca
Lekanta

\begin{tabular}{|c|c|c|}
\hline \multirow[b]{2}{*}{311} & 30 & 20 \\
\hline & 300 & \\
\hline$\left.e_{4}\right)(1$ & Sho & (i.) \\
\hline 91 & 170 & 12 \\
\hline (i.) & 101 & \\
\hline lo(k) & , (1) & \\
\hline
\end{tabular}

\section{Plum 0n Plum}

European Varieties

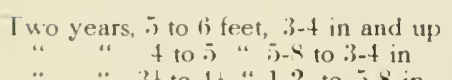

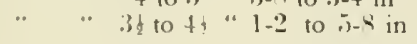

$1600 \quad 150110$

13 (3) 120 (in)

(1) $(\mathrm{OI}) \quad 90 \mathrm{CO}$

Bradshaw

Gen. Hand

$3-4$ in and up $5-4$ to $3-4$ in $1-3$ to $5-4$ in

German Prune

Green Gage

Gueii

Imperial Gage

Lombard

Mloore's Arcric

Pond's Seedling

Reine Claude

Shipper's Pride

Shropshire Damson

Yellow Egg

\begin{tabular}{|c|c|c|}
\hline$\ldots$ & $\begin{array}{l}+75 \\
1001\end{array}$ & 150 \\
\hline .300 & (1) & 50 \\
\hline 4.50 & 30111 & 70 \\
\hline ill & (i) & \\
\hline ixlin & 4.5) & \\
\hline $1+11$ & $25 ;$ & 1000 \\
\hline 275 & 125 & דi \\
\hline (i) & 30 & \\
\hline $\begin{array}{l}450 \\
150\end{array}$ & 10 & 50 \\
\hline
\end{tabular}

\section{Plum 0n Plum}

Japanese Varieties

One and two years, is to $(;$ feet, $3-4$ inch and up

$$
\begin{aligned}
& \text { " " " " " to } 6 \text { " " }-x \text { to } 3-4 \text { in }
\end{aligned}
$$

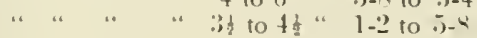

Abundance

Burbank

Prunnus Simoni

Red June

W'ickson

Box Elder

Locust, Black

$$
\text { Honey }
$$

Mulberry, Russian

Peach Pis

Rhubarb

$3-4$ in and up
300
$3(x)$
101
75

$$
\begin{aligned}
& 1-2 \text { to } 5-4 \text { in } \\
& 240 \\
& 200 \\
& 400 \\
& 400
\end{aligned}
$$

\section{Seeds}

Per lb. Per lin lbs.

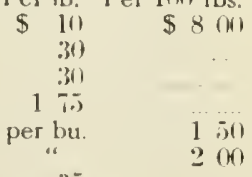




\section{Grape Vines}

Nearly all grapes offered are Fredonia grown and graded to the highest Fredonia standard.

\section{Years No. 1}

\begin{tabular}{|c|c|}
\hline \multicolumn{2}{|c|}{ Per 100} \\
\hline 1400 & 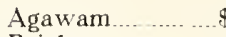 \\
\hline 500 & Brighton \\
\hline 1000 & Campbell's Early \\
\hline 450 & Catawba \\
\hline 350 & Champion ... \\
\hline 17000 & Concord ... \\
\hline 550 & Delaware... \\
\hline 1400 & Elvira \\
\hline 1400 & Agawam. \\
\hline 900 & Brighton \\
\hline 550 & Campbell's Early \\
\hline 200 & Catawba \\
\hline 300 & Champion... \\
\hline 13000 & Concord ... \\
\hline 1000 & Delaware..... \\
\hline 800 & Elvira............... \\
\hline
\end{tabular}

Per 1000
$\$ 3000$

40 on

(j0 00

3000

200

4000

3500
Per 100

1100 Moore's Diamond\$ 350

30000 Moore's Early ... 4 (10)

1500 Niagara .......... 350

1150 Pocklington........... 350

6010 Salem

450 Vergennes.............. 350

1100 Worden .............. 350

400 Wyoming Red... :3 50
Per 1000

$\$ 3000$

3500

300

3000

3000

1 Year No. 1 or 2 Years No. 2
1350 Moore's Diamond 17000 Moore's Early 50 6700 Niagara ............ 250

900 Pocklington........ ? 50

500 Salem ............... 250

$\begin{array}{rrr}1400 & 200 \text { Vergennes........... } & 300 \\ 3000 & 1400 \text { Worden ............... } & 250\end{array}$

$2500 \quad 250$ Wyoming Red. 2 50

\section{Gooseberries}

2 Years, No. 1

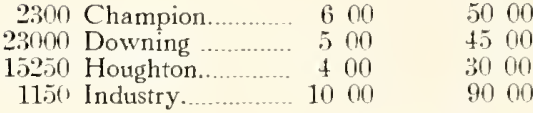

2.200 Josselyn.

300 Mt. Seedling .... +50

300 Pearl ............... 600

800 Smith's.............. 550
20) $(1)$

2250

20 00

20 00

18: 00

500

400

500

50 00

\section{Year, No. 1 or 2 years No. 2}

175 Champion........... 500
1500 Houghton .......... 300
$400(1)$

2000
2200 Industry.

300 Pearl
800

500
7000

400()

\section{Currants}

\section{Years, No. 1}

Per $100 \quad$ Per 1000

1950 Black Champion. 175

4500 Black English...... 175

550 Black Naples........ 1 io

250) Black Victoria..... 1 i5

1100 Cherry............. 300

5.300 Fay's Prolific....... 30 00

450 LaVersailles.......... 300

1000 Lee's Prolific ........ 1 is

2150 London Market... 300

18.j0 Black Champion. 150

1175 Black English..... 1 50

14.56 Black Naples....... 150

1225 Black Victoria.... 150

2700 Cherry .............. 2 25

5600 Fay's Prolific....... 22 25

1250 LaVersailles ........ 20.5

5600 Lee's Prolific....... 1 50

1250 London Market.... 22 25
15) 100

1500

1500

$1.5 \mathrm{Or}$

25 $0(0$

2500

1500

2.) 00

1 year No. 1 ,

1? $\mathrm{j} 0$

1250

12 50

1250

1810

180

1. 00

12.50

1800
800 North Star

1000 Perfection

23010 Red Cross

$33(1)$ Red Dutch

200) Victoria

132.) White Dutch

2050 White Grape.

410 Wilder.

Per 100

300

800

300

300

300

300

300

300
Per 1004)

250

7000

2500

2.) $\mathrm{n}$

2.50()

2) 00

2) 00

Page 8 


\section{Tree Currants}

300 Red Varieties
$\begin{gathered}\text { Per } 100 \\ \$, j 0\end{gathered}$
Strawberries.

Strawberries should be shipped by express

10)(no Strawberries, general assortment, leading kinds

40

250

\section{Fall Bearing Strawberries}

5014) Americus

l11101010 Progressive

125

125

l.j(m) Superb

125

100

1000

1000

\section{Raspberries}

Black $C$ aps should be shipped by express

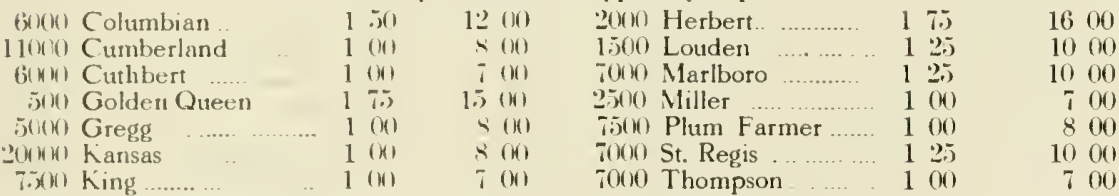

\section{Blackberries}

Root Cutting Plants

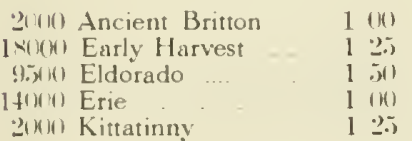

Jnku Lucretia Tips

3.5n Barrs Nammoth, 2y.r ju

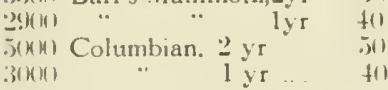

1:31)( Horse Radish

(i.)) Hinalaya Berries

..); Juneberries "2 to $3 \mathrm{ft}$. 5) (III

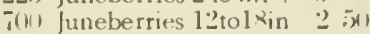

.;) Juneberries (i to l:in 1 in

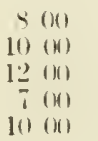

\section{Dewberries}

$\begin{array}{lll}125 & 1000 \\ 80 & 700 \\ 125 & 1000 \\ 1 & 25 & 1000 \\ 125 & 1000 \\ 125 & 1000\end{array}$

Per 100$)$ Per 1000

$100 \quad 800$

\section{Asparagus}

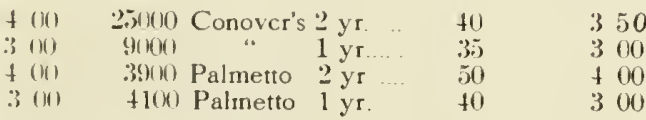

\section{Miscellaneous}

101010 1.5 Loganberries is 190

301 (00 5010 Rhubarb Linnaeus "200

1500

$3(h)$ "Victoria ״

5i)n() Strawbry Raspbry $150 \quad 1000$

$2: 20$ Sage 500

\section{Cuttings}




\section{Fruit Tree Stocks}

Prices subject to change without notice.

\section{American Grown}

Apple Seedlings No. 1, 3-16 inch and up, straight

Medium, $3-16$ inch to $4-16$ inch straight

\section{French Grown}

All goods sold subject to arrival, without engagement, and subject to war conditions.

Apple Seedlings, branched roots, 1 year, transplanted, $3-\overline{5} \mathrm{~mm}$

"Doucine (English Paradise) 1 year, $5-10 \mathrm{~mm}$

Paradise (French) 1 year, $5-10 \mathrm{~mm}$.

Cherry, Mahaleb, 1 year, 2-3 $\mathrm{mm}$

Cherry Seedlings, Mazzard 1 year, $5-9 \mathrm{~mm}$

" " " 1 year, 3-5 mm

$+00$

Plum Seedlings, Mariana, 1 year, $5-10 \mathrm{~mm}$.

1() () ()

Quince Stocks, 1 year, $5-7 \mathrm{~mm}$

Rose Stocks, Canina, 1 vear cuttings, $5-9 \mathrm{~mm}$

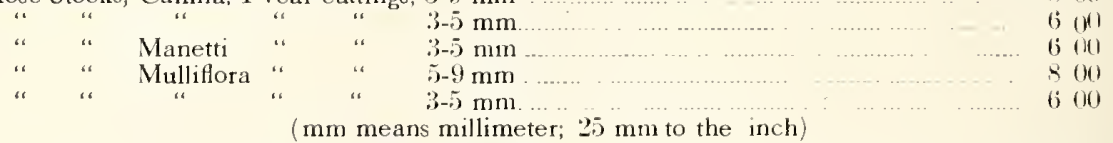

( $\mathrm{mm}$ means millimeter; $25 \mathrm{~mm}$ to the inch)

\section{Root Grafts}

We are still organized for this work and have a good assortment of scions on hand. Send in your orders and we will take the best possible care of them. For description of different kinds of grafts, see our Spring Trade List.

\section{Apple and Crab Piece Root Grafts}

\begin{abstract}
$1000(1)$ and up
$500(1)$ to $100(1) 0$

1000 to 5000
\end{abstract}

\section{Apple and Crab Whole Root Grafts}

5000 and up

1000 to 50000 .

\section{Apple and Crab Whole Root Grafts}

on No. 2 Seedlings

5000 and up

1000 to $50(1)(1$.

\section{Whole Root Grafts With Six lnch Roots}

$5(100)$ and up

$10(10)$ to $50(10)$

\section{Pear Grafts}

Piece Root

Whole Root on No. 1 French branched seedlings

$$
\text { " " } \quad \text { " }
$$

All Grafts Boxed Free. 
(111) Ailanthus, 14.24 inches

\section{Forest Tree Seedlings}

Per 100 in

(6) () " 1"2-1s" "

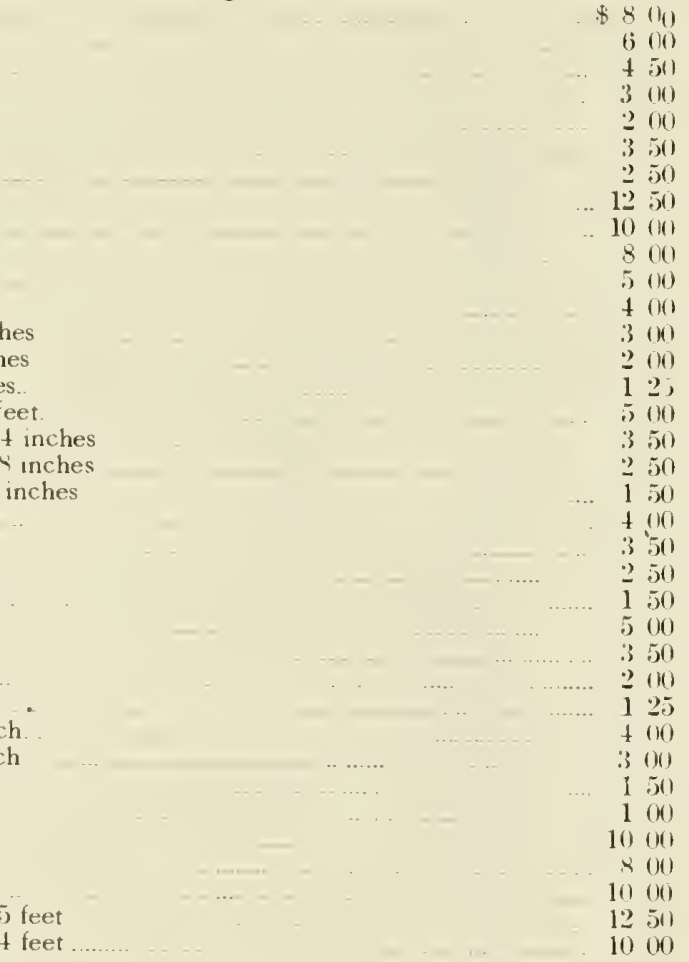

(ii) (1) " 14 to 24 inches

$115(x)$ "12 to 18 inches

3 win Box Elder, 1\% to 24 inches

4 tinc " " 12 to 1 "s inches

3.) Butternut, 2 to 3 feet

1901010 " 14 to 24 inches

$12(n)$ " $"$ "? to 1 is inches

$10(1)$

800

290 Catalpa Speciosa, i3 to 4 feet

$1)$

69900 " "2 to 3 feet

300

$1+(0) 00 \quad$ " $\quad$ ". 14 to 24 inches

200

$+1010100-11-20$

Fink " " "6 to 12 inclies

12 ;

2.5n Elm, American White, 2 to 3 feet

350

24 "

(ii3) " " " 12 to 14 inches

5)

?mon " " " 6 to 12 inches

$+100$

$31(400$ "

3ixn " " " 12 to 15 inches.

1.x(1) " " $" 6$ to 12 inches

250

I(Kin) Maple, 르 to 3 feet

500

Fino " 18 to $2 t$ inches

50

"ख्या) " l') to 18 inches

125

sivo( " 6 to 12 inches

5inu Mulberry, Russian, 18 to :-4 inch

y)(H) “" 12 to $1 *$ inch

?141010 Osage, Orange, No. I

5.j) " "No." No

19010 Sycamore, 1 s to 24 inches

$2: 3111$ " 12 to 18 inches

2(101) Walnut, black, $1<$ to 24 inches

(1) thi Willow, Russian Golden, $t$ to 5 feet

3lini " " "3 to 4 feet

Weeping Trees

Per 111

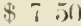

(6) 00

500

3.50

600

$5(10)$

750

(i) 00

$\because 10$

175

150

125

1 (o)

30 " 7 Nioba, \& to 10 feet

5 to 6 feet

4 to i) feet

3 to + feet

“ i) to (i feet

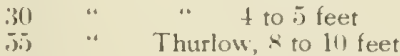

yo " " $" 6$ to 8 feet

$1+5$.

50 " "Wisconsin, s to 111 feet.

20 " " 6 6 to \& feet

90 ..

(1) 0 . 4 to 5 feet
20

1 2.5

100

250

200

1.50

$\because 0$

1 is)

$15+1$

I (110)

15011

$12 . x$

800 


\section{Deciduous Ornamental Trees}

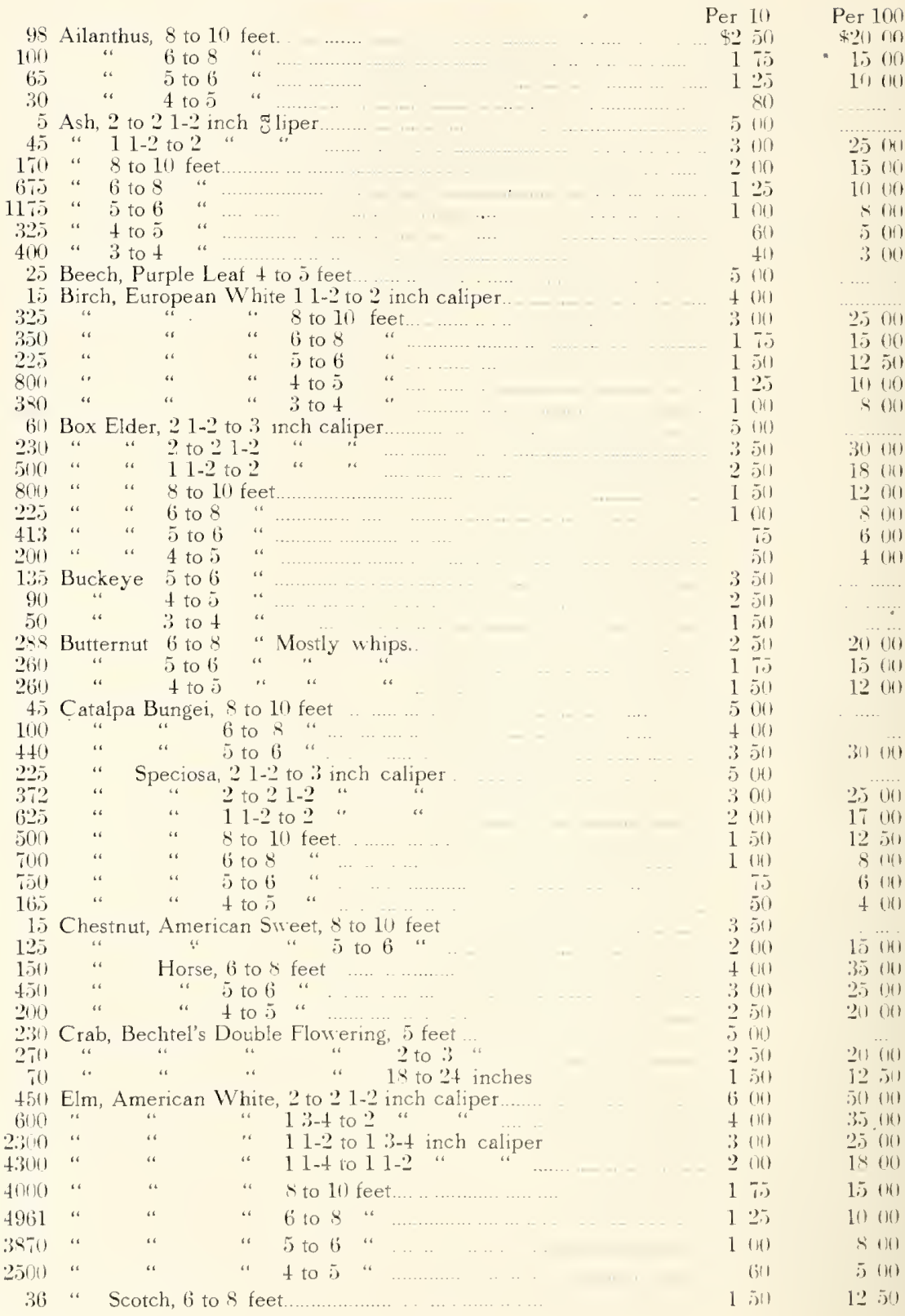




\section{Deciduous Ornamental Trees-Continued}

lili Elun, Seotch, is to 6 "

1:2. " " t to 5 " "

31) .. Vegeta, $13-4$ to 2 inch caliper

2.2. $11-2$ to $] 3-t$ inch caliper

$1+$ " " 4 so $1+1$ feet

i Hackberry, 2 to $2-1-2$ inch caliper

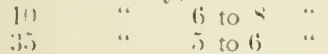

2.; Kentucky Colfee Tree, is to + feet

i) Larch. ") to (i

(1) $"+$ to. $\bar{~}$

1111 “ $" 3$ to + "

111 "2 to 3 "

i Linden. American. $2-$ to $21-2$ inch caliper

li, " $11-2$ to 2 " " "

.j) " . s to lil feet

1!) " . " 6 to 4 "

?.) " " " i to 6 "

in " " to to "

1 .. Argentea, 2 to $\geq 1-2$ inch caliper

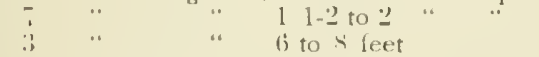

". is to 6

ii .. $\quad$. 4 to.

?1 $\quad$. Dasystyla, $t i$ to 4 feet

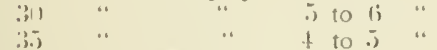

1!!n .. European, (i) to \& "

iliti

ii.j

16 Locust, Black, is to:3 1-2 inch caliper

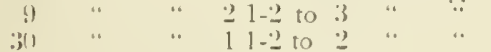

3111 " . " to 111 feer

t<.) ". ". li to \& ".

in ." Honey, it to $x$."

1i. . . . is to $1 \mathrm{i}$

24.) $\quad \therefore \quad \therefore \quad+$ to $i$

31) Magnnolıa Acuminata. is to i feet

i. " . . is to li ".

411 " " 4 to i)

14 Maple, Vormay. "- inch caliper.

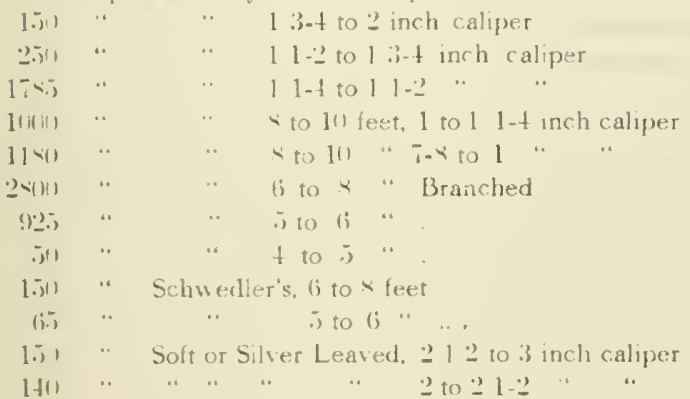

Per 111

$\$ 125$

I III)

(j) 111

is 00

$+(x)$

(5) 00

20

1 हो

$+($ (x)

1 i.)

1 in

13.5

I III

10) (I)

7 i)

3 in

25

IIII)

1 in

111 (1)

7 .

3111

궁

2 a)

4 (1)

: (II)

2 (II)

20

2) (11)

1 )

II) (II)

$+(1) 1$

-) (1)

1 i.)

15

1 . त

125

1 (I)

+ (ih)

3116

2.31

(1) (11)

$x$ (a)

(i) (4)

i) 131

$+(11)$

3. iा

$\because 80$

2. 311

2 (ii)

(i) (II)

i) (111

i) 00

3)
Per 100

$\$ 10$ (1)

8 (1)

201 (1)

1750

12. 51

20) (II)

1751

1251

15) (10)

$12,5)$

12 हा1

10010

र 00

to (II)

35) (11)

301010

2.5) (x)

2) (1)

(1) (11)

3) (x) 


\section{Deciduous Ornamental Trees-Continued}

2500 Maple Soft or Silver Leaved, 8 to 10 feet

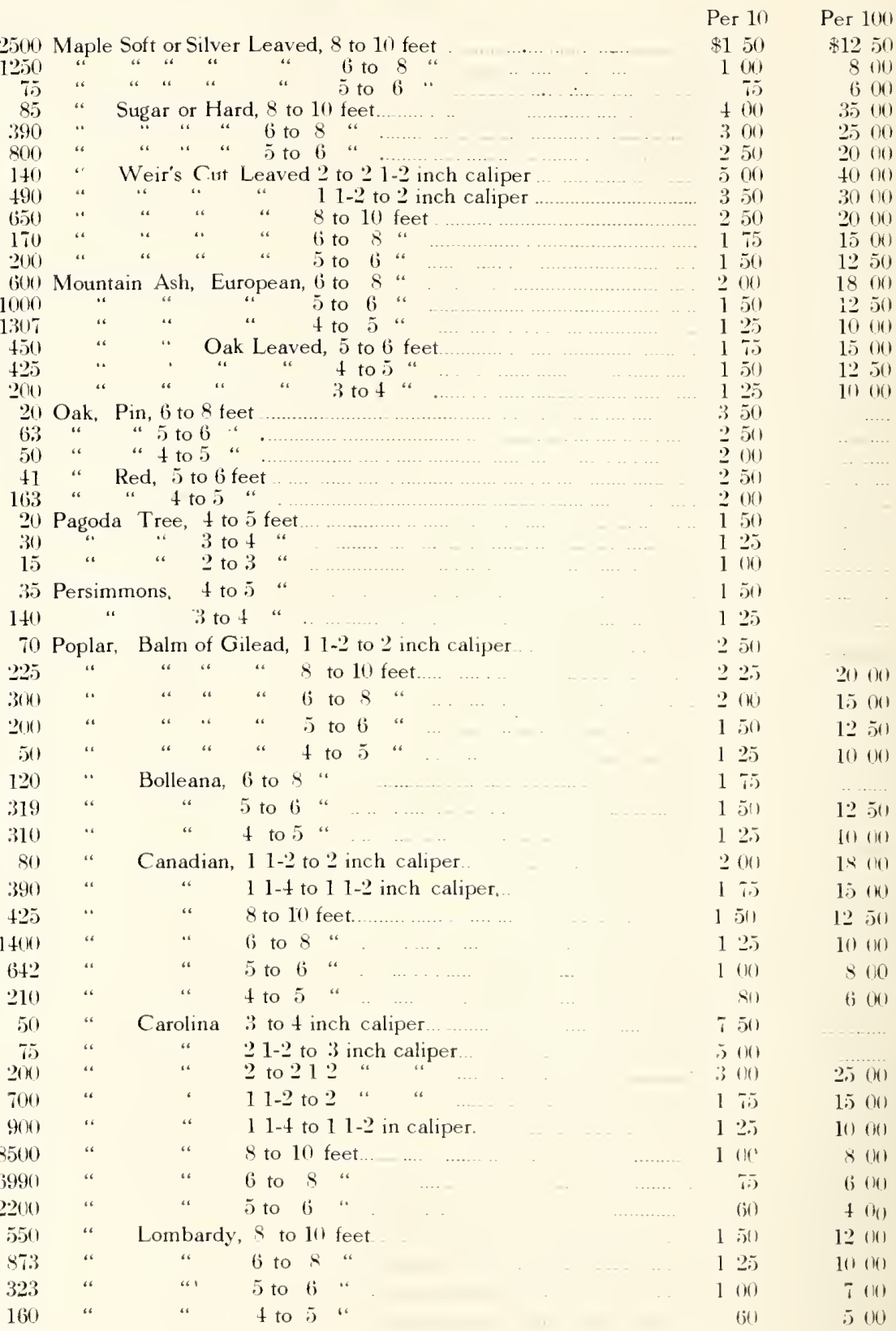




\section{Deciduous Ornamental Trees-Continued}

132 Poplar Norway, $11-2$ to 2 inch caliper

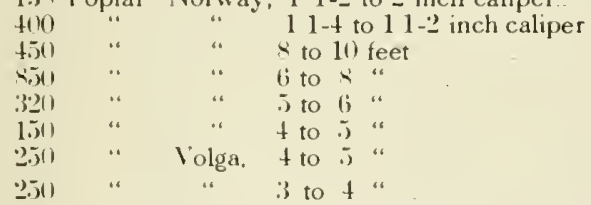

(5) Red Bud or Judas Tree, i) to 6 feet

Per 10

Per 100

l(1)(1) " . " . " " "

3 (1) " " " " " 3 to 4 "

t.2 Sycamore, American, 3 to 4 inch caliper

\begin{tabular}{|c|c|}
\hline 20101 & $\$ 150(1)$ \\
\hline 125 & $11)$ (11) \\
\hline 1110 & $\times 001$ \\
\hline (5) & (; 00 \\
\hline 60) & $+(k)$ \\
\hline 40 & 300 \\
\hline 80$)$ & 6190 \\
\hline (6) & +80 \\
\hline בו & 201110 \\
\hline 2010 & 1500 \\
\hline 150 & 1250 \\
\hline 12 & \\
\hline 650 & 5000 \\
\hline+00 & 3500 \\
\hline 2.50 & 2000 \\
\hline 220 & $18(x)$ \\
\hline$\geq 100$ & 1500 \\
\hline 13 & 11100 \\
\hline 1110 & $x(4)$ \\
\hline 811 & 600 \\
\hline $1 \%$ & \\
\hline 150 & 1250 \\
\hline 12.3 & 1000 \\
\hline
\end{tabular}

5) Thorn, Double, Pink, + to .) feet

2 椡

5il " " "3 to 4 " "

411 . " " White, 4 to 5 feet

t(1) " " " $"$ " to 4 "

111 "Cockspur, jo to 6 feet 20

j)

3.j " " 3 to 4 "

41) Tulip Tree, \& to 10 feet 33

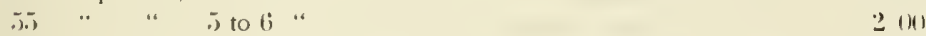

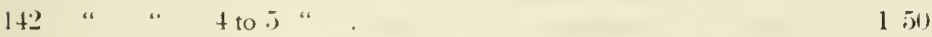

; Varnish Tree, i) to 6 feet.

$2(1)$ " 4 to 501 ;

1.2 Walnut, Black, $21-2$ to $: 3$ inch caliper

i.) " " " 2 to $211-2$ "

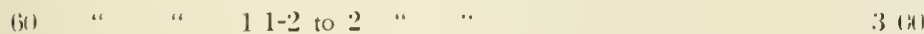

(ii) “ " " o to 6 feet, whips 1 idi

151250

t.i) " " "

1000

(i) " English, 3 to 4 feet

301

$1010 \quad$ i 111

5.5) Willow, Golden, 6 to 8 "

$1+101$ " " क " to 6 "

51)

$+(9)$

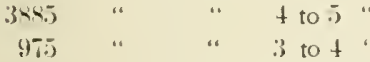

30

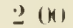

1N11 " Laurel Leaved, ") to li feet

il . " . " 4 to 5 .

100

(i)

(1) 


\section{Ornamental Shrubs}

145 Almonds. Pink, 2 to 3 feet

$\begin{array}{rrr}\text { Per } 10 & \text { Per } 100 \\ 150 & \$ 1250 \\ 1 & 25 & 1000 \\ 1 & 55 & 1500 \\ 1 & 50 & 1250 \\ 1 & 25 & 1000 \\ 1 & 55 & 1500 \\ 1 & 50 & 1250 \\ 125 & 1000 \\ 100 & 800 \\ 80 & 600 \\ 60 & 500 \\ 40 & 300\end{array}$

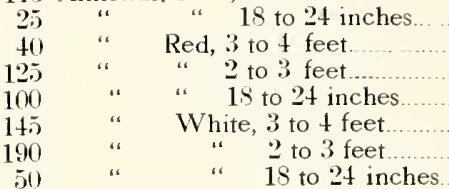

390 Altheas, Bush, Assorted varieties 3 to 4 feet

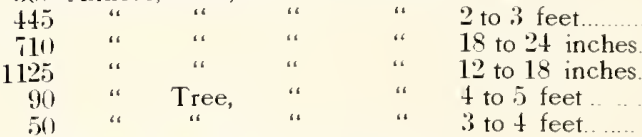

70 Azalea, Mollis, 10 to 15 buds

100

250

675 Barberry, Purple Leaf, 3 to 4 feet

125

2400

"

" " 2 to 3 feet.

250
2200

100

125

2400

3200

“ 19 to 24 inches

Vulgaris, 3 to 4 feet

$$
12 \text { to } 18 \text { inches. }
$$

550 “ “ 2 to 3 feet

600 Buckthorn, 4 to 5 feet

$2000 \quad$ " 12 to 18 inches

50 Butterfly Bush, 2 years

70 Button Bush, 2 to 3 feet

20 " " 18 to 24 inches

90 Calycanthus, 2 to 3 feet.

130 18 to 24 inches

15 Caragana, Pea Tree, 6 to 8 feet

90 " " " " " 4 to 5 feet

140 " " " "3 to 4 feet

300 " " " "2 to 3 feet

275 Cornus Sanguinea, Dogwood, 4 to 5 feet

180 Cornus Siberica.

“ 4 to 5 feet

100 " "

100
50004

25 " " $\quad$ " " 18 to 24 inches

785 " Stolonifera " " 4 to 5 feet

1ix " " " " " " " 4 to 4 feet

190 " " " " "

30 " " " $" 18$ to 24 inches

230 Cranberry, Highbush, 3 to + feet

$315 \quad$ " " 2 to 3 feet

100 " " 18 to 24 inches

70 Currant, Yellow Flowering, 2 to 3 feet

150 " " 18 to $2 \notin$ inches.

190 " Desmodium Penduliflorum, No 1

115 Deutzia Candidissima, 4 to 5 feet
100

125

100

20

150

125

100

125

100

120

I

150

8 (o)

50

1000

800

600

150

1000

800

800

(6) 00

$+011$

1250

1000

800

600

125

1250

10 (1)

100

8110

7.)

50

(6) 10

$+00$

150

1250

$1 \%$

$10(0)$

140

800

i.

6

150

$125(1)$

125

100

80

700

(i)

(j) 00

60

500

17 (i)

1500

150

1250

Page 16 


\section{Ornamental Shrubs,--Continued}

1(1) Deutzia, Candidissima 3 to 4 teet

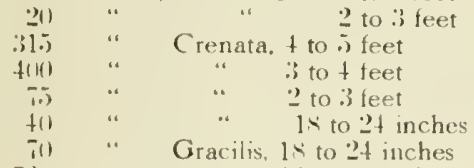

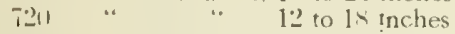

i) $\quad$ ". Lemoneri, 2 to : i teet

140 ". 14 to 24 inches

$1: 3(1)$ " Pride of Rochester, t to is teet

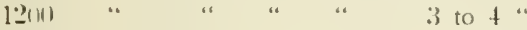

$4+1)$.

120 " " " " " $"$ "

1.) " Waterii, "2 to "3 feet

1sil) Elder, Golden Leaved, is to ti teei

1(i.) " " " th is"

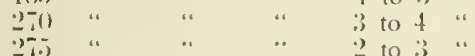

(4) Elaeagnus, Longijes, 2- to :3 "

(i) “ "

i) False Indigo, 2 to :3 feet

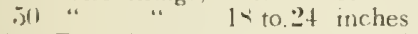

11) Forsythia, Fortuneii, 3 to 4 feet

(ivi) " ? to :3"

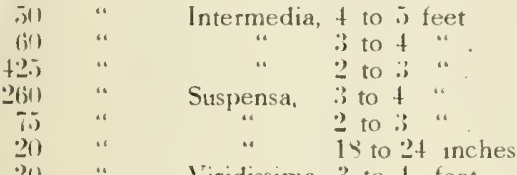

30 ".

24,5 Fringe, Purple, $t$ to ij feet.

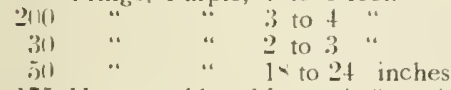

17.) Honeysuckle, Morrowi, 3 to 1 feet

ill ". 2 to :3" "

1111 " ". 18 to 24 inches

12.) “ Tartarian, Pink, Red, 3 to 4 feet

1.j) " " " " " " " " w to 3 "

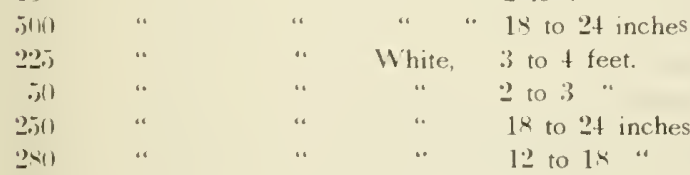

21) Hydrangea, Arborescens, :; to 4 feet

2x) “

i.). " " 1 " to 24 inches

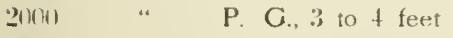

Filli " " 2 to 3 .

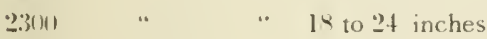

5)(11)

()) 1
“. Tree Form, + to $\overline{\text { if }}$ feet, $\mathrm{T}-16$ to $\$-16$ inch caliper

". .3 to $t$ ". $7-16$ to $4-16$
Per 10

$\$ 1:-5$

1 (in

1 5)

125

1 (1)1

i.)

1 (ii)

i.i

1 (2);

1 (i)

1.3

125

1 (I)

i.)

1 (x)

1 (i)

1 i) 0

125

1 (II)

125

1 (II)

125

1010

$15 i 1$

1 :.)

1 in

1

1 ( )

1 . 11

125

1 हा

Q(1)

1 i)

125

1 (I)

(b)

125

I (III)

रा।

1 .5

1 (II)

(b)

125

1 (101

(bi)

(3)

1 is

1 i)

125

1 :5)

1111

ii)

3170

251
Per 100 .

$\$ 1000$

800

12.

10) (I)

800

(i) (N)

$\times 10$

(i) 0 is

$10 \mathrm{nos}$

( $($ (II)

1.

10) (11)

800

(i) 00

1i) (ii)

12. $5(1$

(1) (1)

sito

12) $(x)$

11) (11)

11) (II)

is (x)

12 (月)

1000

12130

12 511

11) (1)

स०

(1) (1)

(4) (II)

(1) (1)

siti)

5) (10)

10) (b)

$8(K)$

$5(x)$

+ (ii)

15) (II)

12.50

11) $0(1)$

10 (H)

$x(x)$

(i) (II)

-5 (1)

(1) (1) 


\section{Ornamental Shrubs--Continued}

101 Lilac, named varieties, 4 to 5 feet

Per 10

Per 100

146
60

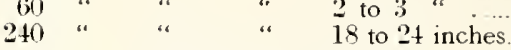

15

85 “"Japonica, 2 to 3 feet.

125

80 " " 18 to 24 inches.

175

125

Josikaea, 2 to 3 feet

2 to 3 feet......

1.50

$\begin{array}{llll}80 & \text { “ } & \text { "“ } & 18 \text { to } 24 \\ 45 & \text { " } & 12 \text { to } 18\end{array}$

100 “ Persian Purple 3 to + feet

12.5

1 (n)

175

150 " " " $" 2$ to 3 "

150 " "

115 " "

100 “. “ “ " White, 3 to 4 feet 18 to 24 inches.

150

1 i.

150

125

200

1 放

2.00

60

120

" " 2 to 3 "

125

Purple, 3 to + feet

18 to 24 inches

125

100

2200 “

100 “"

" 2 to 3 ."

1 i.

“ 12 to 18

400 "White, 2 to 3 feet

20 " “ " 18 to 24 inches

100 " " " 12 to 18

10 Moss Locust, 2 to 3 feet.

140 Prunus Pissardi, 4 to 5 feet

Triloba, ; feet

350 " " 2 to 3 feet

50 " " " 18 to 24 inches.

1 .5.)

175

125

80

8000 Privet, Amoor Kiver North 2 to 3 feet

13000 " " " " " 18 to 24 inches

350 " " $"$ " " 12 to 18 "

2000 " California, 3 to + feet

$\begin{array}{llll}8000 & \text { ". } & \text { " } & 2 \text { to } 3 " \text { " } \\ 7600 & . & \text { ". } & 18 \text { to } 24 \text { inches } \\ 2800 & \text { ". } & \text { " } & 12 \text { to } 18 \text { " }\end{array}$

50 " lbota, 3 to 4 feet.

1225 " " 2 to 3 "

150 " 12 to 18 inches

135 'Polish, 2 to 3 feet

150 " " 14 to 24 inches

900 “V Vulgaris, 2 to 3 feet.

575 " " 18 to 24 inches

50 (1) " 12 to 18 "

35 Quince, Japan Scarlet, 2 to 3 feet

230 " " " 18 to 24 inches

100 Rhododendron, Catawbiense Grandiflora, well budded, 18 to 24 in 281 " Choice named varieties, $1 \%$ to 24 inches.

165 Snowballs. 4 to 5 feet

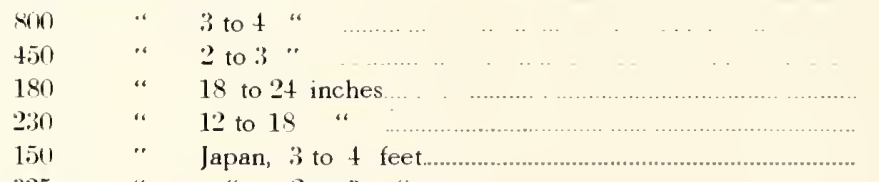




\section{Ornamental Shrubs-Continued}

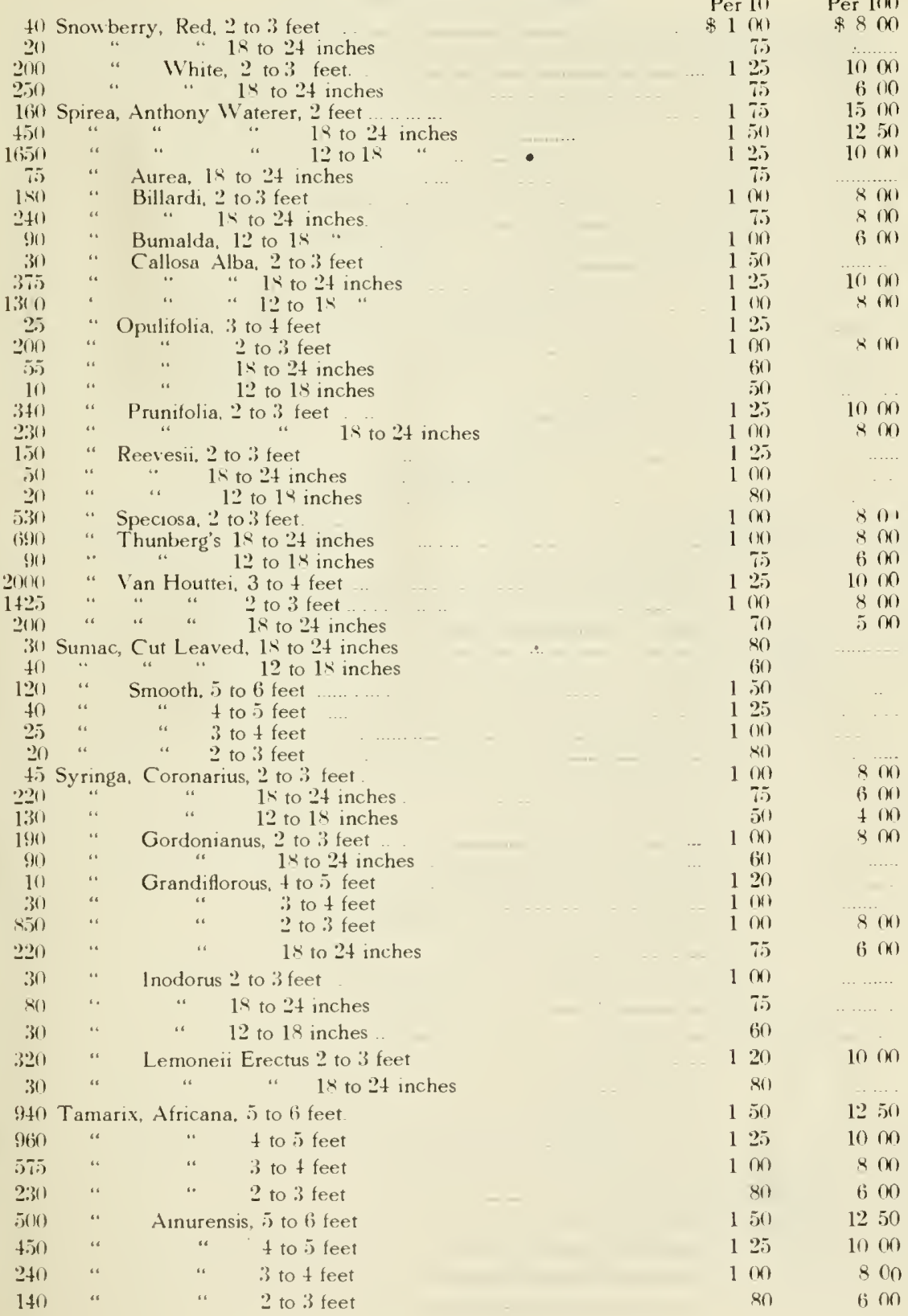




\section{Ornamental Shrubs---Continued}

5n Tamarix, Odessana, 4 to 5 feet.

20 Weigela, Abel Carriere, 3 to + feet

45 " Candida, 3 to 4 feet

$$
\begin{aligned}
& 1 \% \text { to } 24 \text { inches } \\
& \text { Rathke } 3 \text { to } 4 \text { feet }
\end{aligned}
$$

\section{Climbing Vines}

25 Akebia Quinata

380 Ampelopsis Engelmanni

228 Aristolochia Sipho, (Dutchman's Pipe)

125 Bignonia Radicans, (Trumpet Flower)

75 Celastrus or Staft Tree, (Bitter Sweet)

325 “ Madame Edward Andre, (red)

90 " Miss Bateman, (white)

500 " Paniculata (White) 


\section{Evergreens-Transplanted}

All evergreens are handled in the most careful manner, but we recommend digging with a ball of earth and burlapping. Our price for this work is 12 cents for 3 to 4 feet, ii cents for 2 to 3 feet, 8 cents for 18 to 24 inches and $1 ;$ cents for 12 to 18 inches.

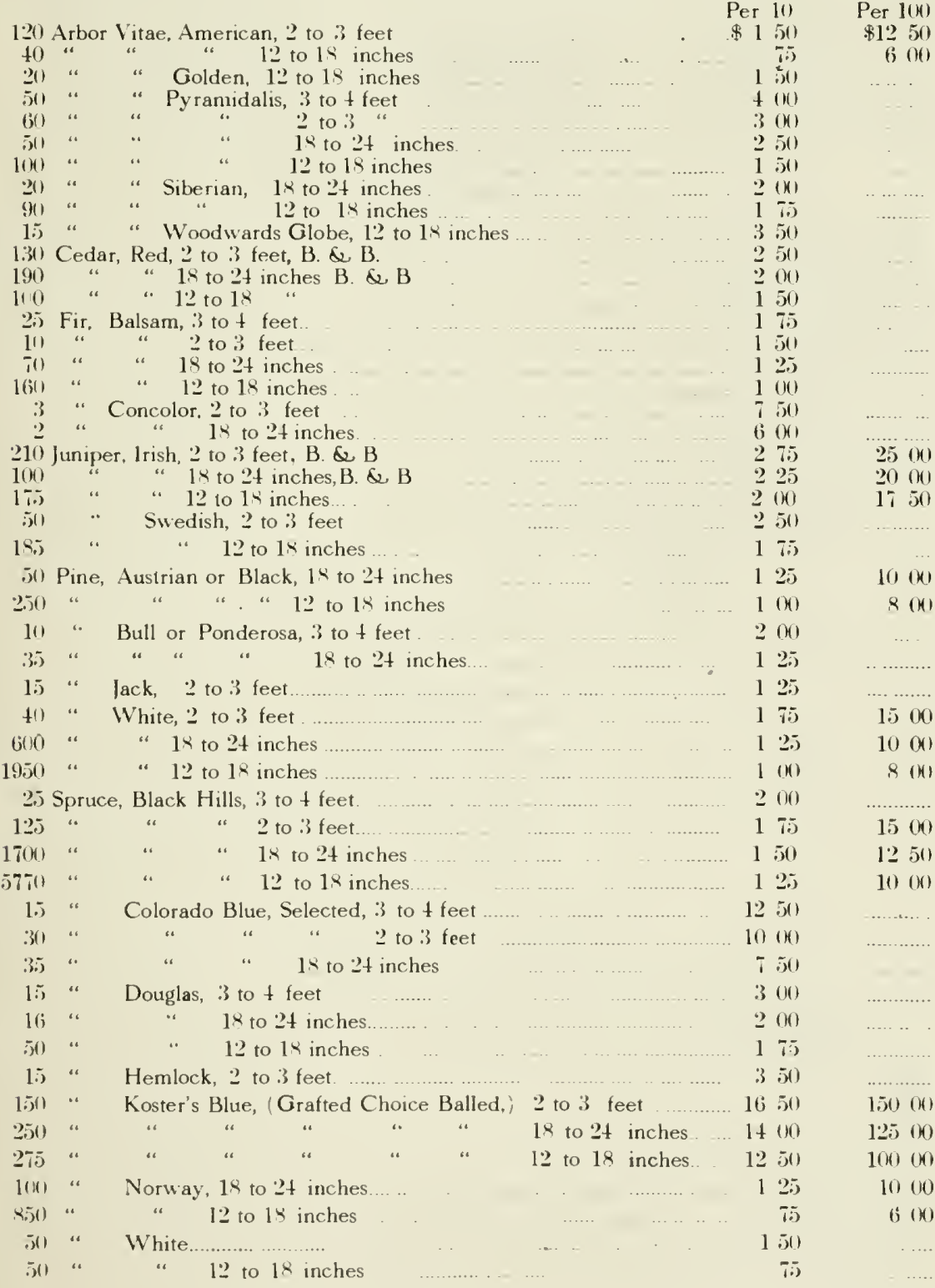




\section{ROSES}

\section{Hybrid Perpetual}

Assorted as follows, No. 1

260 Alfred Colomb

270 Anne de Diesbach

1 '75 Baron de Bonstetten

30 Baroness Rothsehild

90 Captain Christy

130 Captain Hayward

475 Clio

925 Coquette des Alps

110 Duke of Edinburg
1,5 Fisher Holmes

300 Frau Karl Drusehki

1900 General Jacqueminot

150 Hugh Dickson

125 John Hopper

190 Jules HIarrottin

170 Mabel Morrison

130 Madame Gabriel Luizet

$$
\begin{array}{ll}
\text { Per } 10 & \text { Per } 100 \\
\$ 125 & \$ 1000
\end{array}
$$

285 Madame Charles Wood

550 Magna Charta

275 Margaret Diekson

300 Marshall P. Wildel

I25 Mis. John Laing

300 Perle des Blanches

550 Paul Neyron

1250 Prince Camille de Rohan 1000 Uiric'h Brunner

\section{Special Varieties}

26001 American Beauty

$1+0$ General Washington

150

175

375 George Dickson

950 Gruss an Teplitz

(5) () Kaiserin Augusta Victoria

175

12010

(550) Killarney.

175 Killarney White

5(1) La France Pink

175

175

175

16.5 La France White

12.5 Madame Caroline Testout.

1 is

175

b) Madame Plantier

1 (II)

45) Persian Yellow

1 涼

170 Rayon d' Orr (Fine New Yellow Rose

125 Red Maman Cochet.

Assorted as follows, No. 1 200 Rugosa Alba.

Assorted as follows, No 1 425 Conrad F. Meyer

\section{Wichuraiana Hybrids}

Assorted as follows, No. 1 50 Manda's 'Triumph

95. Soutb Orange Perfection 175 Pink Roamer \$.5 Universal Favorite

\section{Moss Roses}

Assorted as follows, No. I 150 Crested Moss

\section{Climbing and Rambler Roses}

1950) American Beauty Climbing

9) American Pillar (One of the best new single Ramblers)

2)() Baltimore Belle

125 Blue Rambler (Veilchenblau) Near Blue

500 Crimson Rambler $X X X$ :3-4 feet, canes

$\begin{array}{llll}6500 & \text { " } & \text { " } & \text { No. } 1 \\ 200 & \text { ". } & \text { No. } 2\end{array}$

450) Dorothy Perkins (Pink)

125 Empress of China (White)

270 Excelsa (Red Dorothy Perkins)

1250) Flower of Fairfield, Everblooming Crimson Rambler

12()

1 (n) 


\section{Climbing and Rambler Roses Continued}

(0) Seven Sisters

17) Tausendschon or Thousand Beauties

-50) White Rambler

\section{Baby Ramblers}

4) Aenchen Muller

100 Baby Tausendschon

17

175

17 放

.) Ellen Poulsen, (Sweet Scented)

30) Erna Teschendorff, (The best of the Red Baby Ramblers)

17.5

210 Jessie, (An improvement on the Old Baby Rambler

175

375 Katherine Zeimet

2:300 Madame Norbert Levavasseur, (Crimson Baby)

1.50) Maman Levavasseur, (Baby Dorothy)

100

3ion Mrs. WV. H. Cutbush

1.50

2) Orleans

20) Yellow Baby Rambler, (small)

NOTE - Scarce sorts will oaly be booked in such proportions in as-

\section{Tree Roses}

Assorted as follow's, No. 1

\section{Hardy Herbaceous Flowering Plants}

Achillea, (The Pearl)

Per 10

Aquilegia, yellow or white. (Columbine)

Asters, white, lavender, pink, red and purple, all named sorts

Cinnamon Vines

Coreopres Lanceolata, deep yellow.

Daisy, Shasta

Dielytra Spectabilis :Bleeding Heart

Gaillardia (Blanket Flower)

Gypsophila Paniculata (Baby's Breath)

Hibiscus, Crimson Eye

Hollyhocks, choice double.

Iris, German mixed

"Japan

"Named, we have a very choice selection, any shade or color

Moonflower, strong :3 inch pots

Pinks, Hardy 2 inch pots

$$
\text { " "Clumps. }
$$

Phlox, choice latest sorts 



\section{Imported Ornamental Stock for Plant-}

\section{ing in Nursery Row}

These stocks have Leen carefully inspected by us, and are in good condition ready for prompt shipment. We would suggest that orders be placed promptly before the assortment is broken.

520 Acer Plataroides, Norway Maple, 12 to 18 inches.......................... 80

1000 Acer Pseudo-platanus, Sycamore Maple, 2 to 3 feet.............. 1750

750 Acer Pseudo-platanus, Sycamore Maple, 18 to 24 inches......... 1500

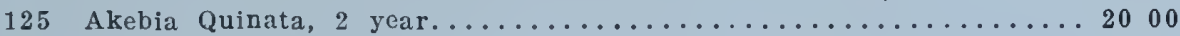

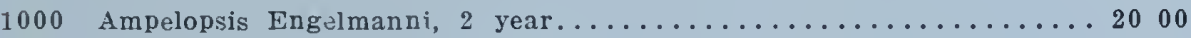

250 Ampelopsis Quinquefolia, Am. Ivy or Virginia Creeper, 2 year...... 1500

1570 Ampelopsis Veitchii, Japan or Boston Ivy, 2 year............. 1500

100 Aristolochia Sipho, Dutchman's Pipe, 2 year................... 00

70 Berberis Darwin, Darwin's Barberry (finest of all the Barberries) 2 yr 2000

1000 Berberis Thunbergi, Thunberg's or Japanese Barberry, 18 to 24 in... 2500

6000 Berberis Thunbergi, Thunberg's Japanese Barberry, 12 to 18 in.... 2000

600 Berberis Thunbergil, Thunberg's or Japanese Barberry, 6 to $12 \mathrm{in} . \ldots 1500$

725 Betula Alba Eup. White Birch, 2 to 3 feet...................... 1250

3500 Betula Alba Eup. White Birch, 18 to 24 inches................ 1000

500 Betula Alba, Eup. White Birch, 12 to 18 inches............. 800

100 Bignonia Grandiflora, 2 year..................... 5000

400 Buxus Arborescens, Box Tree, 2 year..................... 1600

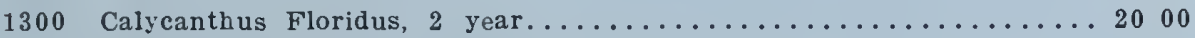

50 Cercis Canadensis, Red Bud or Judas Tree, 2 year.............. 2000

200 Chamacerasus Morrowi, Jap. Eush Ho eysuckle. Yellowish White 2 yr. 2500

425 Chamaecerasus Tartarica Alba, White Tartarian Honeysuckle, 2 year 2250

75 Chamaecerasus Tartarica Rosea, Pink Tartarian Honeysuckle, 2 узаг 2500

175 Chamaecrasus Tartarica Rubra, Red Tartarian Honeysuckle 2 year... 2500

1000 Cornus Sanguinea Fup. Red Osier Dogwood, 2 year............ 1500

1300 Cornus S:berica, Red Branched Dogwood, 2 year............... 1750

425 Crataegus Coccinea, Fl. Pl., Paul's Double Scarlet Thorn, 2 year.....\$60 00

175 Desmodium Penduliflorum, 2 year.................. 5000

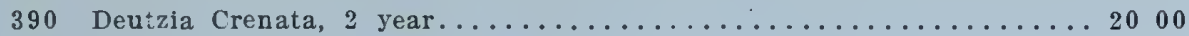

190 Deutzia Gracilis Rosea, 2 year...................... 2000

150 Deutzia Lemoineii, 2 year............................ 2000

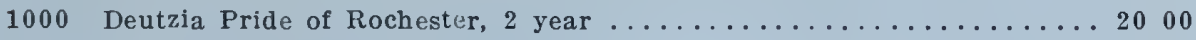

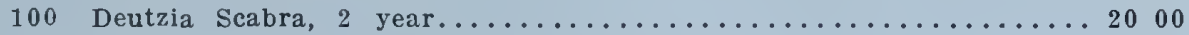

380 Diervilla, Weigela, Abel Cairriere, Rose, 2 year............. 4000

300 Diervilla Weigela, Candida White, 2 year.................... 3250

1200 Diervilla, Weigela, Eva Rathke, Crimson, 2 year............ 4000

500 Diervilla, Weigela Rosea.................................... 3500

100 Diervilla, Weigela, Nana Variegated, 2 year................. 3000

600 Euonymous Europeus, European Strawberry or Spindle Tree, 2 year... 1250

60 Exochorda Grandiflora, Pearl Bush, 2 year..................... 3500

250 Forsythia Fortuneii, Fortune's Golden Bell, 2 year............ 2250

200 Forsythia Fortuneii, Variegated Aurea, Yellow Variegated, 2 year... 2250

600 Forsythia Fortuneii Intermedia, 2 year..................... 2000

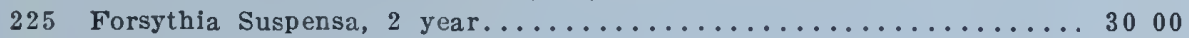

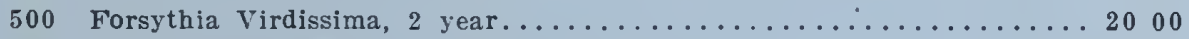

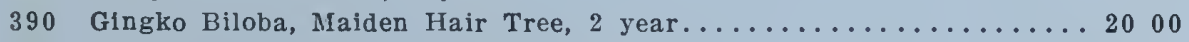

3900 Hydrangea Paniculta Grandiflora, 2 year................... 3000

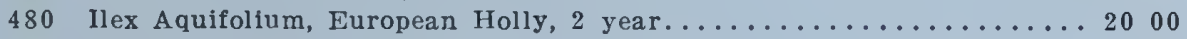

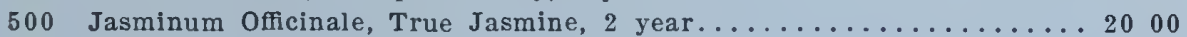

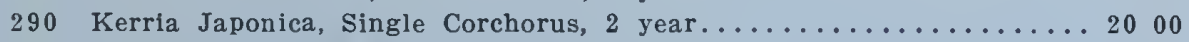

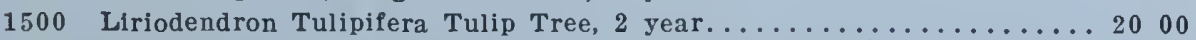

590 Lonicera Belgica Monthly Fragrant Honeysuckle, 2 year........... 2500

475 Lonicera Flava, Yellow Trumpet Honeysuckle, 2 year........... 3000

700 Lonicera Halleana, Hall's Japan Honeysuckle, 2 year........... 2500 
Lonicera Punicea, Red Coral Honeysuckle, 2 year............. 25. 00

795 Lonicera Sempervirens, Scarlet Trumpet Honeysuckle, 2 year...... 2500

340 Lonicera Sinensis, Chinese Honeysuckle, 2 year.............. 2500

175 Magnolia Acuminata, Cucumber Magnolia, 2 year.............60 00

30 Magnolia Soulangeana, Soulange's Magnolia, 2 year.............. 12500

100 Philadelphus Coronarius, Garland Syringa or Mock Orange, 2 year. . . 25 00

500 Philadelphus Grandiflorus, Large Flowered Syringa, 2 year....... 2000

900 Philadelphus Gordonianus, Gordon's Syringa, 2 year........... 2500

1000 Philadelphus Lemoineii, Lemoine's Syringa, 2 year............ 2000

560 Platanus Orientalis European Sycamore, or Plane Tree 2 to 3 feet...22 50

2885 Platanus Orientalis, European Sycamore, or Plane Tree, 18 to 24 in... 20 00

1330 Platanus Orientalis, European Sycamore, or Plane Tree, 12 to 18 in.. 1800

50 Populus Bolleana, Bolleana Poplar, 2 year.................25 00

65 Quercus Alba, American White Oak, 2 year............... 2000

100 Quercus Palustris, Pin Oak, 2 year .................... 2000

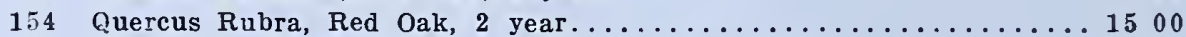

240 Robina Bessoniana, Thornless Locust, 2 year...............5 5000

90 Robinia Decaisneana, Pink Flowered Locust, 2 year............60 00

590 Rhus Cotinus, Purple Fringe or Smoke Tree, 2 year........... 2000

39 Rhus Glabra, Smooth Sumach, 2 year.................... 3000

215 Rhus Glabra, Smooth Laciniata, Cut Leaved Sumach, 2 year...... 6000

500 Rosa Rugosa Rubra, 3 year.......................... 20.00

50 Sambucus Acutiloba, American Cut leaved Elder, 2 year......... 5000

320 Spirea Bumalda, Rose, 2 year......................... 2000

380 Spirea Callosa, Fortune's Spirea, Pink, 2 year................ 1800

670 Spirea Prunifolia Flora Pleno, Bridal Wreath, White, 2 year..... 2500

470 Spirea Thunbergii, white, 2 year....................... 2000

700 Symphoricarpus Racemosus, White Snowberry, 2 year........... 1800

700 Symphoricarpus Vulgaris, Indian Currant, Coral Berry or Red Snow-

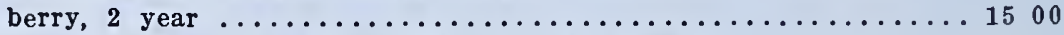

160 Syringa, Josikaea, Hungarian Lilac, Purple, 2 year............. 30 C0

390 Syringa, Persica, Purple Persian Lilac, 2 year............... 5000

195 Syringa, Persica, Alba, white Persian Lilac, 2 year........... 5000

150 Syringa, Rothomagensis, Alba, White, 2 year............... 4000

100 Rubra de Marley, Dark Red, 2 year..................... 2750

700 Vulgaris, Common Purple Lilac, 2 year. . . . . . . . . . . . . . . . . 2000

250 Vulgaris, Alba, Common White Lilac, 2 year................ 2500

Syringa Lilacs, Named Varieties Grafted................. 6000 Single Flowered Varieties

46 Congo, vinous red (fine)

36 Frau Bertha Dammann, white

110 Marie LeGraye, White

\section{Doubled Flowered Varieties}

81 Madam Casimir Perier, cream white (very fine)

80 President Grevy, blue (fine)

264 Tamarix Africana, African Tamarisk, Pink, 2 year.......................... 00

150 Tamarix Gallica, French Tamarisk, Pink, 2 year.............. 1800

100 Tamarix Hispida, Bright Carmine, 2 year................ 4000

300 Tamarix Odessana, Russian Tamarisk, Lavender Purple, 2 year...... 2000

260 Tilia Europea, European Linden, 18 to 24 inches............... 2000

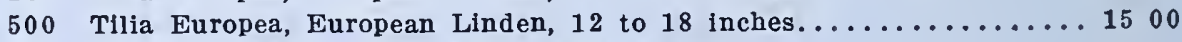

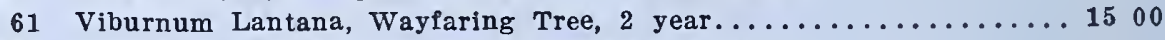

1300 Viburnum Opulus. High Bush Cranberry, 2 year............. 2000

800 Viburnum Opulus. Sterilis, Snowball, 2 year................ 2500

925 Viburnum Plicatum, Japanese Snowball, 2 year............... 8000

283 Wistaria Multijuga, Japanese Wistaria, Dark Blue, 2 year.......50 00

400 Wistaria Sinensis, Chinese Wistaria, Blue, 2 year............. 4500

335 Wistaria Sinensis, Alba, Chinese Wistaria, White, 2 year........ 5000 


\section{Paeonies}

180 Festiva Maxina

350 Baron de Rothschild. pink 75 Caroline Marguther, red

168 Chinese Rubra, pink

50 Doyenne de Enghein, red 22 Festiva

100 Madam Breon, rosy flesh

50 Ofticialis Rubra

\author{
200 Perfection, pink \\ 20 Prolifera Tricolor, fleshy yellow \\ 80 Queen Perfectiun, white \\ 900 Queen Victoria, white \\ 125 Rosa Fragrans, pink \\ 120 Triumph de Paris, white
}

\section{Miscellaneous Greenhouse Plants}

Carnation, strong 2 inch pots, pink, red and white.............................. if

Chrysanthemums, strong 2 inch pots .......................................... 70

Ferns, In variety.

"Asparagus, 2 inch

"Boston 2 inch

" Sprengeri 2 inch pots

" Whitmani 2 inch

Geraniums, either double or single, any color, 2 inch

Hydrangea, for house culture, small

Lily of the Valley, in clumps of 10 pips each

Pansies.
600

600

700

700

700

700

700

600

1i) 00

1500

$+00$

\section{Tender Bulbs and Tubers For Spring Planting}

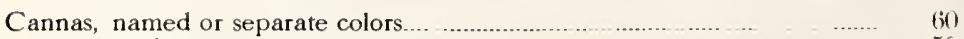

Caladium, Esculentum, (Elephant Ear) large

Dahli'as, choice, double named sorts in the following colors, red, pink, yellow, white and variegated

" in separate colors, not named

" in mixed colors

Gladiolus, choice mixed all colors " separate colors “ named Lilium, Tigrinum (Tiger Lily)

Maderia Vines.

Tube Roses, Excelsior Pearl, first class bulbs Mexican Single, fine. 